Acta vet. scand. $1977,18,374-383$.

From the National Veterinary Institute, Oslo, Norway.

\title{
TUBERCULIN REACTIONS IN BULLS AND BOARS SENSITIZED WITH ATYPICAL MYCOBACTERIA FROM SAWDUST
}

By

Finn H. Fodstad

\begin{abstract}
FODSTAD, FINN H.: Tuberculin reactions in bulls and boars sensitized with atypical mycobacteria from sawdust. Acta vet. scand. 1977, 18, 374-383. - Due to a planned export from a combined bull and boar station, more than 70 boars and 100 bulls were examined by tuberculin tests. Distinct reactions to avian tuberculin appeared in about half of the animals. Many of them also reacted to bovine tuberculin. For diagnostic purposes, many of the reactors were slaughtered, and samples from these and from the environment were examined bacteriologically. Strains of Mycobacterium avium were isolated from only 2 out of 14 reacting boars and from none of the 23 reacting bulls. No isolation of Mycobacterium bovis was made. However, atypical mycobacterial strains, classified as Runyon Group III and IV, were isolated from 3 boars, 2 bulls, 1 pigeon and from many samples of sawdust. The isolation of identical fast-growing mycobacterial strains from the sawdust used in the pens for the reacting boars and bulls, was especially remarkable. The strains differed enzymatically and biochemically from those isolated from other sources. This indicated a possible sensitization of the animals with similar mycobacterial strains. Possible cross-reactions to avian and bovine tuberculin were investigated in tuberculin assays with guniea pigs and pigs sensitized to one of the mycobacterial strains isolated. Distinct reactions to both avian and bovine tuberculin appeared in all the animals. From these results it was concluded that the tuberculin reactions in the boars and the bulls were not due to any tuberculous infection in the herd, but to a sensitization of the animals with atypical mycobacteria.
\end{abstract}

tuberculin reactions; atypical mycobacteria; s a w d u s t; bull; b o a r.

Tuberculin cross-reactions are well-known phenomena in both veterinary and human medicine. Such reactions may cause diagnostic errors with consequences for health status as well as economy. The reactions are usually due to antigenic relationships between mycobacteria of different species. Typical exam- 
ples are the strong reactions to avian tuberculin in cattle suffering from paratuberculosis. Corresponding examples in human medicine are reactions to mammalian tuberculin in persons sensitized to strains of Mycobacterium balnei occurring in salt water swimming-pools.

Very few tuberculin tests in animals are carried out in Norway at present. This is due to the successful eradication of bovine tuberculosis, the last known case in this country being diagnosed in 1964. However, animals for export are still routinely tested.

During the spring of 1975 deep-frozen swine semen was to be exported from a combined bull and boar station located in the south-eastern part of Norway. Prior to the export of semen, the donors were tuberculin tested. Distinct reactions with at least $4 \mathbf{~ m m}$ increase in skin thickness appeared in many pigs. The aim of the following epidemiological study was to investigate the cause of these reactions.

\section{MATERIALS AND METHODS}

\section{Tuberculin status}

Twenty-seven out of 46 boars had reacted in the first routine test with avian tuberculin. In January 1976 new comparative tuberculin tests were done in 50 boars. Sixteen reacted to avian tuberculin and 12 more pigs reacted to both avian and bovine tuberculin. Twelve non-reactors and 13 reactors from the spring of 1975 were still alive. In the repeated tests 5 of the former and 11 of the latter reacted. Twelve young boars not previously examined also gave distinct reactions to avian tuberculin.

Due to the high frequency of reactors in the boar population, it was decided to test the bulls at the station. During the spring of 1975 tuberculin tests were done on 34 adult and 65 young bulls. Reactions to avian tuberculin appeared in 10 and 9 animals, respectively. In January 1976, 92 bulls were tested. Thirty of these reacted to avian tuberculin.

\section{Material from slaughtered animals and the environment}

For diagnostic purposes many of the reactors were slaughtered and samples from various lymph nodes, liver, spleen and lungs were submitted to our laboratory for bacteriological examinations. 
The samples examined bacteriologically were as follows:

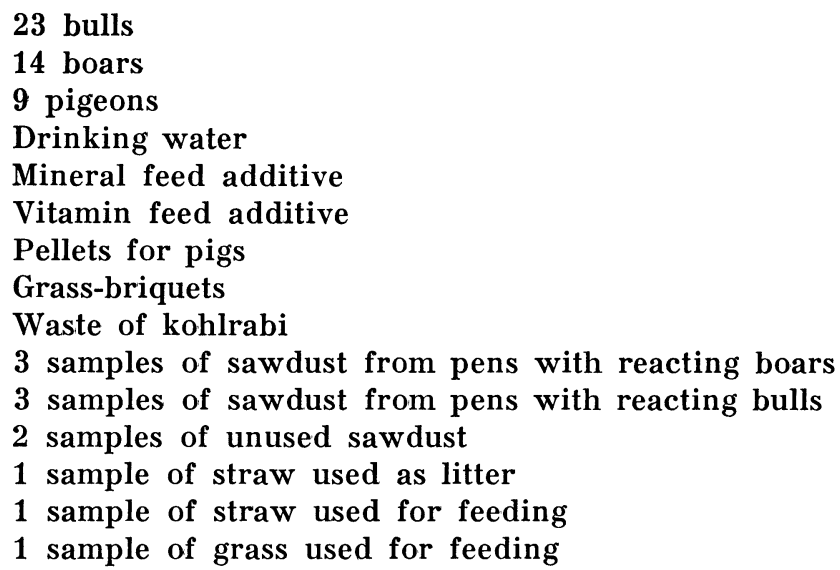

\section{Bacteriological examinations}

L $\phi$ wenstein's, Petragnani's and Stonebrink's culture media were used for the isolation of bacteria.

Tissue samples were examined macroscopically for lesions and then ground in a blender. Five \% oxalic acid was used as decontaminant. After grinding, the samples were transferred to sterile tubes and incubated at room temperature for $20 \mathrm{~min}$. The tubes were centrifuged at $1200 \times \mathrm{g}$ for $7 \mathrm{~min}$. and the supernatants were removed and the sediments spread onto the surface of the culture media. Samples from fodder and sawdust were treated in the same way. After some days colonies of moulds and fungi occurred in many tubes inoculated with material from sawdust. In order to control this growth, the addition of various fungistatics to the culture media was tried. Best results were obtained with Fungizone $\AA$, Squibb (Fodstad, to be published). A concentration of 60 i.u. Fungizone/ml medium almost completely inhibited growth of moulds and fungi with no harmful effects on the growth of mycobacteria.

Water samples were filtered through Millipore filters with pore size $0.2 \mu$. The filters were cut into small pieces which were ground and decontaminated with oxalic acid in a blender. All culture tubes were incubated at $37^{\circ} \mathrm{C}$ for 8 weeks with readings at 7 day intervals.

From each tube with growth, a representative number of colonies were isolated and secondary cultures were established. The strains isolated were classified according to Runyons clas- 
sification of atypical mycobacteria (Runyon 1959), and characterized by means of colony morphology, growth curves, ability to grow at various temperatures and various biochemical and enzymatic reactions (Virtanen 1960, Wayne 1961, Wayne et al. 1964, Käppler 1964, Kubica et al. 1966).

\section{Histological examinations}

Tissue-samples for histology were fixed in $10 \%$ buffered formalin. Paraffin-embedded sections were stained with haematoxylin-eosin and by Ziehl-Neelsen's staining method.

\section{Biological assay in guinea pigs}

Assays were performed for testing possible cross-reactions to avian and bovine tuberculin in animals sensitized with atypical mycobacteria originating from sawdust. White male guinea pigs, weighing about $500 \mathrm{~g}$ served as test animals.

Sensitizing procedure. Seven guinea pigs were sensitized with a suspension of heat killed, dried organisms of $M$. avium, strain D4ER, in light paraffin oil, and 7 other guinea pigs with a corresponding suspension of an atypical mycobacterial strain, $T-61^{x}$, isolated from sawdust used in a pen with tuberculin reacting boars. The suspensions contained $1 \mathrm{mg}$ dried organisms per ml. Each animal was given 4 intracutaneous injections of $0.1 \mathrm{ml}$ on the abdomen.

Tuberculin products and dilutions. Avian and bovine synthetic medium tuberculins, produced and standardized at our institute, and a sensitin, produced from strain $\mathrm{T}-61^{\mathrm{x}}$, were used in the assay. Dilutions of the 3 products containing $0.8,0.2$ and $0.05 \mu \mathrm{g}$ protein per $\mathrm{ml}$ were prepared. Phosphate-buffered saline served as diluent.

Skin testing procedure. Each guinea pig was given 9 intracutaneous injections of $0.1 \mathrm{ml}$ of the dilutions. The injections were distributed at random at 9 different body sites in order to compensate for possible systematic errors due to variations in degree of sensitivity between different body areas. The reactions were read by measuring the diameter of the area of erythema 24 hrs. after injection, using a plastic plate etched with circles of diameters 1 to $35 \mathrm{~mm}$. All reactions were read by 2 persons. The dilutions were labelled in a code unknown to the observers. 


\section{Biological assay in pigs}

Two pigs, each weighing approx. $40 \mathrm{~kg}$, were fed a culture of strain T-61x, mixed in milk, 5 times over a period of 3 weeks. Comparative tuberculin tests, using avian and bovine tuberculin, were carried out before the administration of bacteria and 3 weeks after the last feeding of the culture. The tests were done at the ear.

\section{RESULTS}

\section{Isolation of mycobacteria}

Already after 1 week, scanty growth occurred in some tubes from sawdust samples. During the following 5-6 weeks growth also appeared in various other samples. The results of the classification studies are listed in Table 1.

Mycobacterium avium was isolated from mesenteric lymph nodes from 2 of the 14 boars, but from none of the 23 bulls examined. In 1 of the 2 boars some mesenteric lymph nodes were slightly enlarged. Greyish nodules, partly calcified, could be seen subcapsularly. Histologically, there were inflammatory lesions with the formation of miliary and submiliary nodules with mainly epitheloid cells and lymphocytes. In the other pig, some greyish spots were seen on the cut surface of 1 mesenteric lymph node. On histological examination accumulations of epitheloid cells were observed.

Strains of mycobacteria, classified as Runyon Group III, were isolated from 3 boars and from 1 bull. Enzymatic and biochemical reactions of these strains were identical with those of Mycobacterium avium with the exception of a quite strong reduction of nitrate. Greyish miliary nodules could be seen in some mesenteric lymph nodes from the 3 infected pigs. Histologically, there were miliary nodules with epitheloid cells, lymphocytes and cellular debris. No lesions were found in the bull.

Two strains of mycobacteria, isolated from a mesenteric lymph node of a bull and from a pigeon, were classified as Runyon Group IV. The 2 strains differed only in their ability to reduce nitrate. No lesions were found in the animals.

Fast-growing mycobacterial strains were isolated from sawdust samples taken from each of the 3 pens with reacting boars and from 1 pen with reacting bulls. The test reactions indicated identity between these strains. Another fast-growing strain, isolated from waste of kohlrahi, gave exactly the same reactions. 


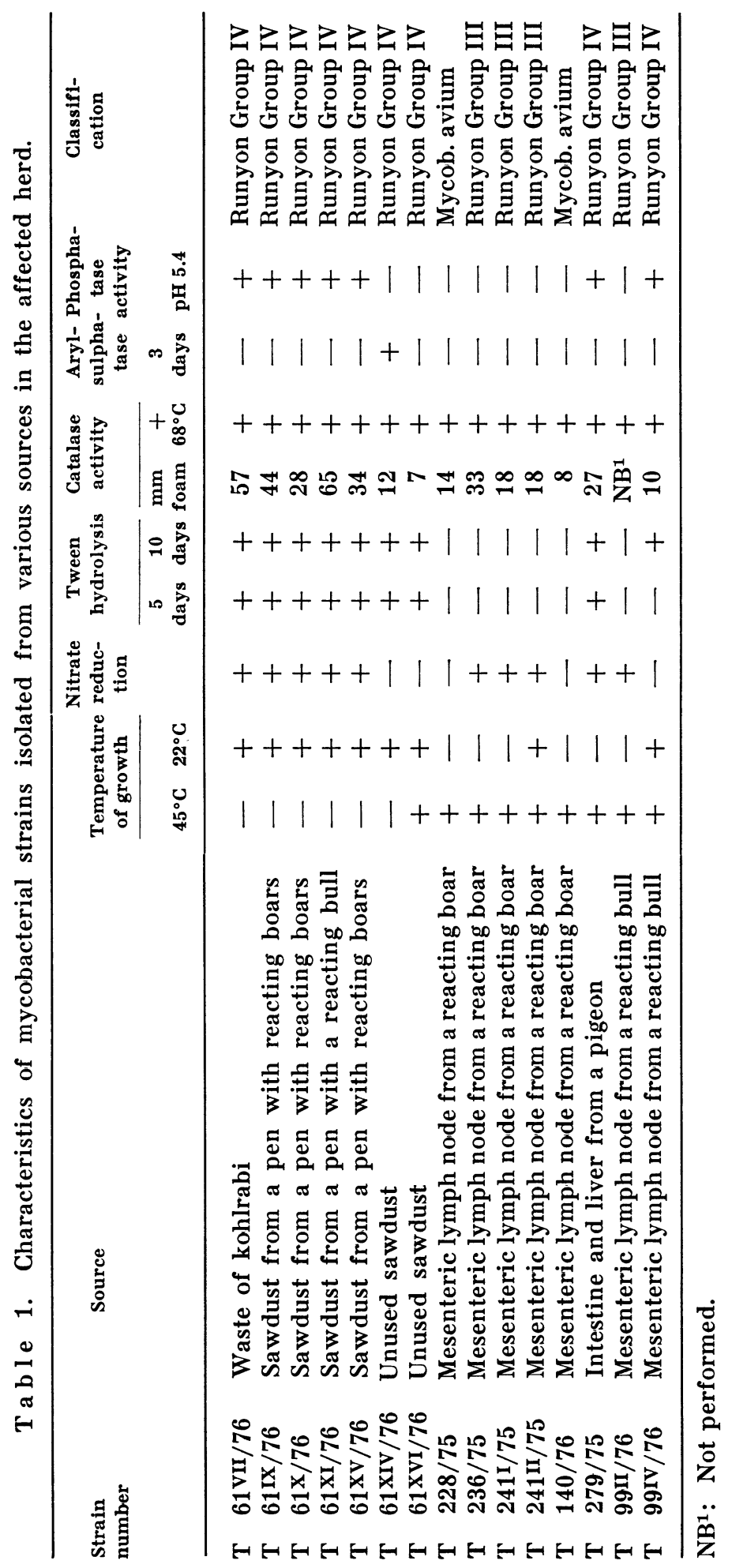


Two other mycobacterial strains, also classified as Runyon Group IV, were isolated from unused sawdust. However, these strains differed biochemically and enzymatically from each other and from the other strains isolated.

\section{Biological assay in guinea pigs}

The atypical mycobacterial strain $\mathbf{T}-61^{x}$, used as sensitizing agent in the assay, was one of the identical strains isolated from sawdust used in pens with reacting boars.

The average size of the reactions to the 9 test preparations in the 2 groups of guinea pigs, are listed in Table 2 .

Ta b le 2. Cutaneous reactions to three different sensitins in 14 guinea pigs, 7 sensitized with strain T-61x and 7 with strain D4ER. Diameters of erythema in $\mathrm{mm}$.

\begin{tabular}{|c|c|c|c|c|c|c|c|c|c|}
\hline \multirow{3}{*}{$\begin{array}{l}\text { Sensi- } \\
\text { tizing } \\
\text { agent }\end{array}$} & \multicolumn{9}{|c|}{ Sensitins } \\
\hline & \multicolumn{3}{|c|}{ avian tuberculin } & \multicolumn{3}{|c|}{ bovine tuberculin } & \multicolumn{3}{|c|}{ T-61x sensitin } \\
\hline & $0.8 \mu \mathrm{g}$ & $0.2 \mu \mathrm{g}$ & $0.05 \mu \mathrm{g}$ & $0.8 \mu \mathrm{g}$ & $0.2 \mu \mathrm{g}$ & $0.05 \mu \mathrm{g}$ & $0.8 \mu \mathrm{g}$ & $0.2 \mu \mathrm{g}$ & $0.5 \mu \mathrm{g}$ \\
\hline Strain $T-61 x$ & 12.7 & 10.6 & 7.6 & 12.1 & 11.3 & 7.9 & 17.3 & 14.8 & 12.3 \\
\hline Strain D4ER & 13.3 & 11.0 & 9.1 & 11.4 & 7.8 & 6.3 & 6.6 & 4.7 & 4.7 \\
\hline
\end{tabular}

In each group of guinea pigs the homologous preparations gave the strongest reactions. However, the degree of specificity of the preparations differed considerably. The reactions to the sensitin, prepared from the atypical mycobacterial strain $T-61^{x}$, were very strong in the homologous group of guinea pigs, while the reactions to this sensitin in the guinea pigs, sensitized to the avian strain D4ER, were hardly recognizable. Avian tuberculin showed a much smaller degree of specificity. Although the largest diameters of erythema were recorded in guinea pigs sensitized to avian bacilli, this tuberculin gave strong and distinct reactions in both groups or animals. The average size of reactions to bovine tuberculin were almost similar to those obtained with avian tuberculin in guinea pigs sensitized to strain T-61x, but smaller in guinea pigs sensitized to the avian strain.

\section{Biological assay in pigs}

The readings of the tuberculin tests carried out before the administration of bacteria cultures, showed no increase in skin 
thickness. The results of the readings carried out 3 weeks after the last feeding, are listed in Table 3.

Table 3. Reactions to avian and bovine tuberculin in pigs sensitized with atypical mycobacteria isolated from sawdust.

Skin fold thickness in $\mathrm{mm}$.

\begin{tabular}{lcccccc}
\hline & & \multicolumn{2}{c}{ Avian tuberculin } & & \multicolumn{2}{c}{ Bovine tuberculin } \\
\cline { 3 - 5 } & $\begin{array}{r}\text { Before } \\
\text { testing }\end{array}$ & $\begin{array}{c}\text { after } \\
\text { 24 hrs. }\end{array}$ & $\begin{array}{c}\text { after } \\
48 \text { hrs. }\end{array}$ & & $\begin{array}{c}\text { after } \\
24 \text { hrs. }\end{array}$ & $\begin{array}{c}\text { after } \\
\text { 48 hrs. }\end{array}$ \\
\hline Pig no. 1 & 4 & 8 & 8 & 8 & 8 \\
Pig no. 2 & 3 & 9 & 9 & 8 & 8 \\
\hline
\end{tabular}

\section{DISCUSSION}

Due to the unexpected large number of tuberculin reacting animals in the herd, the possible spread of a tuberculous infection had to be considered, and any sources of infection would have had to be traced. However, the bacteriological findings did not reveal any specific mycobacterial infection in the herd. In addition to 2 strains of Mycobacterium avium, only atypical mycobacterial strains were isolated from the animals and the environment. The isolation of atypical strains from sawdust was not surprising. Corresponding findings have occasionally been made in our laboratory, and similar findings have been reported elsewhere. Beerwerth \& Popp (1971) isolated mycobacterial strains classified as Runyon Groups II, III and IV from sawdust. They also reported the isolation from sawdust of 18 mycobacterial strains identical to Mycobacterium avium, with the exception of a strong reduction of nitrate. This finding is in accordance with the pattern of the Runyon Group III strains isolated from 3 boars and from 1 bull in our investigations. Uhlemann et al. (1975) isolated strains of Mycobacterium avium and different atypical mycobacterial strains from sawdust and from wood shawings. The most striking result is the observation that all the mycobacterial strains isolated from sawdust used in pens with reacting animals, showed biochemical and enzymatic identity, different from the pattern of strains isolated from unused sawdust. This observation indicated that these strains were the sensitizing agent. However, animals sensitized with Runyon Group IV mycobacteria rarely react distinctly to avian or bovine tuberculin (Fodstad, unpublished). 
In the present study, however, performed in guinea pigs sensitized with one of the fast-growing strains isolated from sawdust, distinct reactions to the homologous sensitin as well as strong reactions to avian and bovine tuberculin were recorded. A corresponding tuberculin assay carried out in pigs confirmed these results. This indicates a particular tendency of the strongly sensitizing organism to settle in animal environments which will thereby serve as a source for further spreading. Even though quite identical organisms were not isolated from unused sawdust, the results of the bacteriological examinations show that sawdust may be an important reservoir for atypical mycobacteria and may, therefore, probably also serve as a primary source for the sensitizing mycobacterial strains described. The bacteriological findings, together with the results from the tuberculin assays, strongly indicate that the tuberculin reactions in the bulls and boars tested were cross-reactions to avian and bovine tuberculin in animals sensitized with atypical mycobacteria, and not due to a tuberculous infection in the herd.

The possibility of tuberculin cross-reactions in animals sensitized with some of the other atypical mycobacterial strains isolated, has not been investigated in the present study.

\section{REFERENCES}

Beerwerth, W.\& K. Popp: Zur epizootologischen Bedeutung der Sägemehleinstreu für das Auftreten der Schweinetuberkulose. (Epizootiological significance of sawdust bedding for the occurrence of tuberculosis in pigs). Zbl. Vet.-Med. B 1971, 18, 634-645.

Käppler, W.: Über die Verbreitung einer „sauren“ Phosphatase innerhalb der Gattung Mycobacterium. (On the occurrence of "acid" phosphatase in mycobacteria). Beitr. Klin. Tuberk. 1964, 129, $210-213$.

Kubica, G. P., W. D. Jones, V. D. Abbott, R. E. Beam, J. O. Kilburn \& J. C. Carter: Differential identification of mycobacteria. I. Tests on catalase activity. Amer. Rev. resp. Dis. 1966, 94, 400405.

Runyon, $E$. H.: Anonymous mycobacteria in pulmonary disease. Med. Clin. N. Amer. 1959, 43, 273-290.

Uhlemann, J., R. Held, K. Müller \& H. Dürrling: Schweinetuberkulose in einem Mastkombinat nach Einstreu von Hobel- und Sägespänen. (Swine tuberculosis in a fattening unit following use of wood shawing and sawdust for litter). Mh. Vet.-Med. 1975, 30, $175-180$.

Virtanen, S.: A study of nitrate reduction by mycobacteria. Acta tuberc. scand. 1960, Suppl. 48. 
Wayne, L. G.: Recognition of Mycobacterium fortuitum by means of a three-days phenolphtalein test. Amer. J. clin. Path. 1961, 36, $185-187$.

Wayne, L. G., J. R. Doubek \& R. L. Russel: Classification and identification of mycobacteria. I. Tests employing Tween 80 as substrate. Amer. Rev. resp. Dis. 1964, 90, 588-597.

\section{SAMMENDRAG}

Tuberkulin-reaksjoner hos okser og råner sensibilisert med atypiske mykobakterier fra sagflis.

Ved en rutinemessig tuberkulin-kontroll av ca. 70 råner og 100 okser viste de fleste til dels sterke reaksjoner overfor aviært tuberkulin. Mange reagerte samtidig for bovint tuberkulin. Flere av reagentene ble slaktet. Sammen med forskjellige prøver fra miljø og fôr ble organmateriale fra 14 råner og 23 okser unders $\varnothing k$ t bakteriologisk.

Mycobacterium avium ble isolert fra mesenterial-lymfeknuter hos to råner mens Mycobacterium bovis ikke ble isolert fra noe dyr. Derimot ble stammer fra atypiske mykobakterier, klassifisert til Runyons gruppe III og IV, isolert fra 3 råner, 2 okser, 1 due samt fra flere sagflispr $\emptyset$ ver. Særlig bemerkelsesverdig var isoleringen av hurtigvoksende stammer med ensartet biokjemisk og enzymatisk reaksjonsm $\varnothing$ nster fra sagflisprøver tatt fra bingene med tuberkulin-positive råner og okser. Tilsvarende reaksjonsm $\emptyset$ nster ble ikke funnet hos stammer isolert fra andre kilder. En sensibiliserende effekt hos de nevnte ensartede stammer overfor aviært og bovint tuberkulin ville kunne forklare det store antall tuberkulin-reaksjoner $\mathrm{i}$ den unders $\varnothing \mathrm{kte}$ besetningen. En slik effekt ble bekreftet $i$ tuberkulin-fors $\phi k$ utf $\varnothing \mathbf{r t}$ på marsvin og griser.

Tuberkulin-reaksjonene $\mathrm{i}$ den unders $\varnothing$ kte besetning antas derfor å ha vært kryss-reaksjoner overfor aviært og bovint tuberkulin i dyr sensibilisert med atypiske mykobakterier.

(Received May 4, 1977).

Reprints may be requested from: Finn H. Fodstad, The National Veterinary Institute, P. O. Box 8156, Oslo Dep., Oslo 1, Norway. 